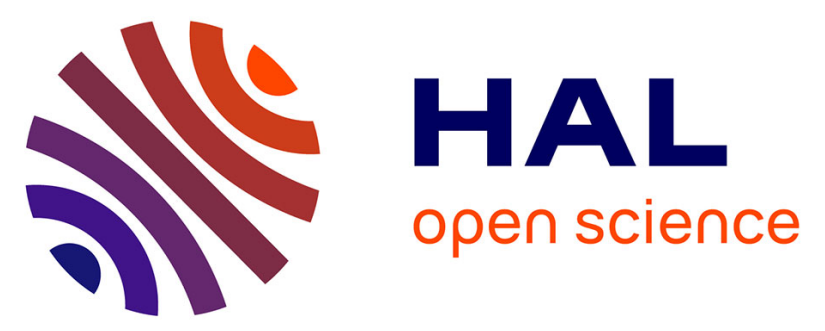

\title{
Artemisinin-Derivative-NHC-gold(I)-Hybrid with enhanced cytotoxic activity through inhibiting NRF2 transcriptional activity
}

Chen Zhang, Pierre-Yves Fortin, Guillaume Barnoin, Xue Qin, Xing Wang, Alvaro Fernandez Alvarez, Christian Bijani, Marie-Lise Maddelein, Catherine Hemmert, Olivier Cuvillier, et al.

\section{To cite this version:}

Chen Zhang, Pierre-Yves Fortin, Guillaume Barnoin, Xue Qin, Xing Wang, et al.. ArtemisininDerivative-NHC-gold(I)-Hybrid with enhanced cytotoxic activity through inhibiting NRF2 transcriptional activity. Angewandte Chemie International Edition, 2020, 59 (29), pp.12062-12068. 10.1002/anie.202002992 . hal-02442823v2

\section{HAL Id: hal-02442823 \\ https://hal.science/hal-02442823v2}

Submitted on 17 Nov 2020

HAL is a multi-disciplinary open access archive for the deposit and dissemination of scientific research documents, whether they are published or not. The documents may come from teaching and research institutions in France or abroad, or from public or private research centers.
L'archive ouverte pluridisciplinaire HAL, est destinée au dépôt et à la diffusion de documents scientifiques de niveau recherche, publiés ou non, émanant des établissements d'enseignement et de recherche français ou étrangers, des laboratoires publics ou privés. 


\title{
Artemisinin-Derivative-NHC-gold(I)-Hybrid with enhanced cytotoxic activity through inhibiting NRF2 transcriptional activity
}

\author{
Chen Zhang[a,b]\$, Pierre-Yves Fortin $[\mathrm{b}] \$$, Guillaume Barnoin $[\mathrm{a}] \$$, Xue Qin ${ }^{[a]}$, Xing Wang[a], Alvaro \\ Fernandez Alvarez ${ }^{[a]}$, Christian Bijani[a], Marie-Lise Maddelein[b], Catherine Hemmert ${ }^{*}[a]$, \\ Olivier Cuvillier ${ }^{*}[\mathrm{~b}]$, Heinz Gornitzka*[a]
}

[a] Dr. C. Zhang, G. Barnoin, X. Qin, X. Wang, Dr. A. Fernandez Alvarez, Dr. C. Bijani, Dr. C. Hemmert, Prof. Dr. H. Gornitzka LCC-CNRS, Université de Toulouse, CNRS, UPS, Toulouse, France E-mail: hemmert@lcc-toulouse.fr and gornitzka@lcc-toulouse.fr

[b] Dr. C. Zhang, Dr. P.-Y. Fortin, Dr. M.-L. Maddelein, Dr. O. Cuvillier Institut de Pharmacologie et de Biologie Structurale, Université de Toulouse, CNRS, UPS, Toulouse, France E-mail: olivier.cuvillier@inserm.fr

\$ These authors contributed equally to this work.

Supporting information for this article is given via a link at the end of the document

\begin{abstract}
A family of original hybrid complexes combining two biological active motifs, an artemisinin derivative and a cationic bis(NHC)gold(I) unit, has been synthesized. One of these complexes, $\mathbf{2 a}$, has been analyzed by single-crystal $X$-ray diffraction. 2a shows strong anticancer activities on a large panel of representative human cancer cell models (prostate, breast, lung, liver, bladder, bone, acute and chronic myeloid leukemias) with $\mathrm{Gl}_{50}$ values in $\mathrm{nM}$ range, together with a high selectivity. An original and distinctive mechanism of action, through inhibition of the redox antioxidant NRF2 transcription factor - strongly associated with aggressiveness and resistance to cancer therapies - has been evidenced. 2a could remarkably sensitize to sorafenib in HepG2 liver cells, in which dysregulated NRF2 signaling is linked to primary and acquired drug resistance. 2a also inhibited NF-KB and HIF transcriptional activities, which are also associated with progression and resistance in cancer. Our findings provide evidence that hybrid $(\mathrm{NHC})$ gold(I) molecules represent a new class of organometallic hybrid molecules that may yield new therapeutic agents.
\end{abstract}

\section{Introduction}

Artemisinin and its derivatives, well known as antimalaria drugs ${ }^{[1]}$ draw more and more attention for other medical applications such as viral diseases and cancer treatments. ${ }^{[2]}$ One mechanism of action, discussed in the context of cancer, is based on ROS formation, due to an activation of artemisinin derivatives by iron from free heme. ${ }^{[2 \mathrm{~d}, 3]}$ This activation takes mainly place in mitochondria, where fresh heme is produced continuously. It has been evidenced that mitochondria-targeting artemisinin derivatives show stronger anticancer activities than non-mitochondria-targeting ones. ${ }^{[3 a]}$ Another class of molecules targeting mitochondria in cancer cells, are cationic Nheterocyclic carbene $(\mathrm{NHC})$ gold $(\mathrm{I})$ complexes. ${ }^{[4]}$ During the last few years we focused our research on the optimization of NHC gold(I) complexes for anticancer activities. ${ }^{[5]}$ Herein we present the synthesis, cytotoxicity, selectivity and mechanistic studies of cationic bisNHC gold(I) complexes incorporating an ether derivative of dihydroartemisinin (DHA, semi-synthetic derivative of artemisinin and metabolite of all artemisinin compounds) as building block.

\section{Results and Discussion}

Synthesis, Characterization and Crystal Structure

The NHC precursors of an original class of DHA-NHC-Au hybrid molecules have been obtained by connecting DHA to methylimidazole via aliphatic linkers of different lengths C3 to C5. For this, commercially DHA was reacted with a bromoalcohol in the presence of boron trifluoride etherate catalyst according to the procedure described by Haynes for the C3-derivative, leading to the single $\beta$-isomers DHA-C3 to DHA-C5 (see Figure 1). ${ }^{[6]}$ The obtained bromoalkyl DHA derivatives were reacted with methyl imidazole leading to the corresponding carbene precursors 1a to 1c with yields ranging from 39 to $92 \%$. The formation of the target gold complexes has been achieved by two approaches. For the C3 derivative, the convenient transmetalation route involving the mild base $\mathrm{Ag}_{2} \mathrm{O}$, followed by an ion exchange with $\mathrm{AgNO}_{3}$ and subsequent addition of $\mathrm{Au}\left(\mathrm{SMe}_{2}\right) \mathrm{Cl}$ has been used. For the $\mathrm{C} 4$ and $\mathrm{C} 5$ derivatives, the direct metalation involving $\mathrm{K}_{2} \mathrm{CO}_{3}$ and $\mathrm{Au}\left(\mathrm{SMe}_{2}\right) \mathrm{Cl}$ has been applied. The gold(I) complexes 2a-c were isolated after purification by chromatography as white solids with yields of 31 to $84 \%$. All compounds were characterized by ${ }^{1} \mathrm{H}$ and ${ }^{13} \mathrm{C}$ NMR spectroscopy, high-resolution mass spectrometry and elemental analysis (see the Supporting Information). ${ }^{13} \mathrm{C}$ NMR spectroscopy unequivocally evidences the formation of the cationic gold(I) complexes with resonance of the carbenic carbons located at 183.6-183.7 ppm. HRMS spectra of 2a-c exhibit the classical peak for the cationic fragment $[\mathrm{M}-\mathrm{X}]^{+}$and elemental analysis correspond to the general $\left[\mathrm{AuL}_{2}\right][\mathrm{X}]$ formula. Moreover, single crystals suitable for $\mathrm{X}$-ray structure analysis have been obtained by gas phase diffusion from diethyl ether to a saturated solution of $\mathbf{2 a}$ in acetonitrile (Figure 1 ). In the solid state the gold(I) shows the typical linear coordination stabilized by two NHC ligands. The NHC planes are crossed around the $\mathrm{C}$ $\mathrm{Au}-\mathrm{C}$ axis with torsion angles from $116^{\circ}$ to $138^{\circ}$. It is remarkable that the bulky DHA-derivative groups are on the same side of the central bisNHC gold motif. This is due to an aurophilic 


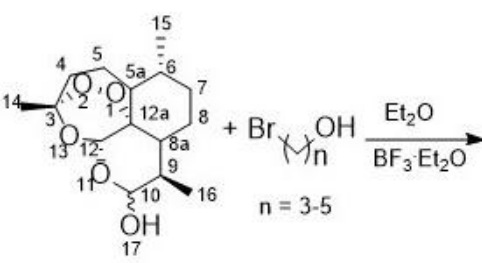

DHA

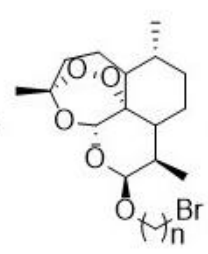

DHA-C3, 45\% DHA-C4, $29 \%$ DHA-C5, $21 \%$

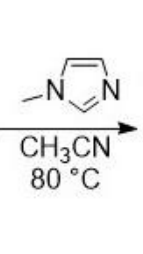

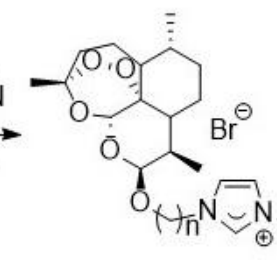

$$
\begin{aligned}
& \text { 1a: } n=3,65 \% \\
& \text { 1b: } n=4,92 \%
\end{aligned}
$$$$
\text { 1c } n=5,39 \%
$$

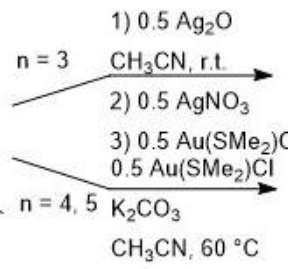

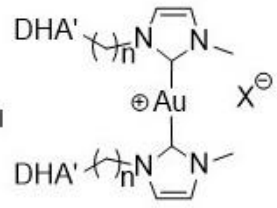

2a: $\mathrm{n}=3, \mathrm{X}=\mathrm{NO}_{3}, 84 \%$ 2b: $n=4, X=C l, 80 \%$ 2c: $n=5, X=C l, 31 \%$
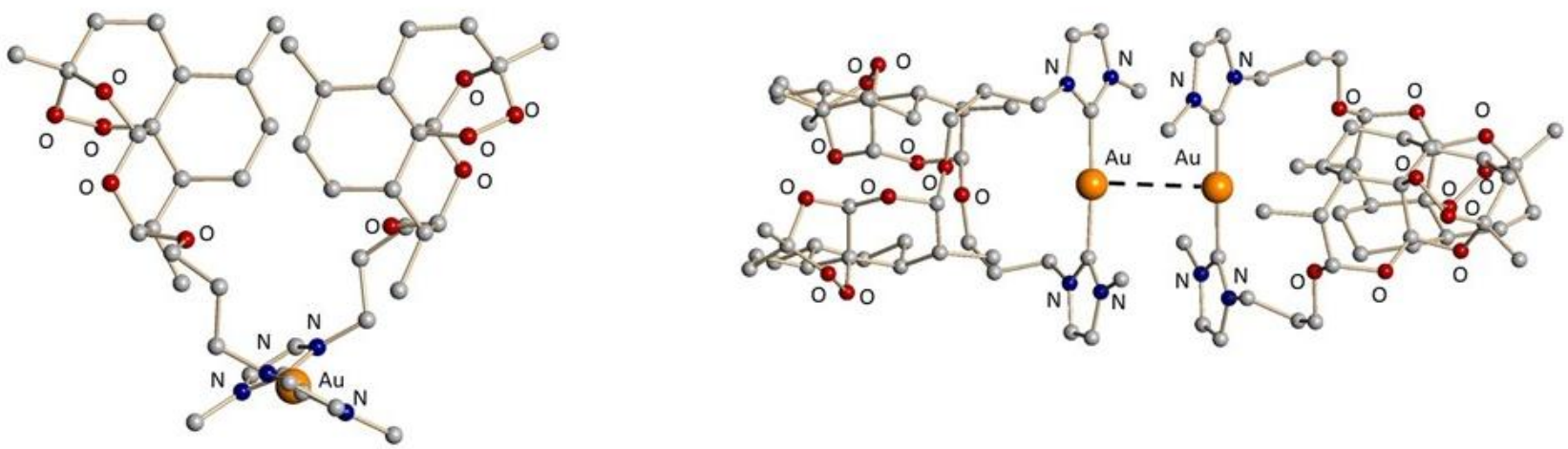

Figure 1. On the top: synthesis of proligands $\mathbf{1 a - c}$ and gold(I) complexes $\mathbf{2 a - c . ~ O n ~ t h e ~ b o t t o m ~ i s ~ d e p i c t e d ~ t h e ~ s t r u c t u r e ~ o f ~ t h e ~ c a t i o n i c ~ p a r t ~ o f ~} \mathbf{2 a}$ in the solid state. One bisNHC gold unit looking along the C-Au-C axis on the left and dimeric arrangement on the right.

\section{Cytotoxicity and Selectivity}

In a first screening, precursors 1a-c and complexes 2a-c were evaluated for their in vitro cytotoxic abilities against the PC-3 prostate cancer cell line and two non-cancer cell lines (NIH3T3 fibroblastic and RPWE-1 epithelial prostatic cells) (Table 1). The imidazolium salts $1 \mathrm{a}-\mathrm{c}$ showed no cytotoxic effects $\left(\mathrm{Gl}_{50}>20\right.$ $\mu \mathrm{M})$, while complexes 2a-c exhibited strong antiproliferative activities with $\mathrm{Gl}_{50}$ values between $20 \mathrm{nM}$ and $70 \mathrm{nM}$. The selectivity indexes $\left(\mathrm{SI}=\mathrm{Gl}_{50}\right.$ (non-cancer cell line) $/ \mathrm{Gl}_{50}$ (cancer cell line)) of 2a-c gave nearly the same values concerning NIH3T3 cells ranging from 15.5 to 16.7 , while RPWE- 1 cells gave a more differentiated result with the highest $S I=6.9$ for $2 \mathbf{a}$. As reference drugs for our studies, along with DHA, we tested the gold complex auranofin, used for treating inflammatory arthritis, and now proposed for drug repurposing in cancer, ${ }^{[7]}$ which recently entered phase $\mathrm{I} / \mathrm{II}$ trials in lung cancer in combination with mTOR inhibitor sirolimus (Clinicaltrials.gov ID NCT01737502). Moreover, a published cationic bisNHC gold(I) complex 3, containing a methyl and a quinoline substituents, ${ }^{[8]}$ and a mixture of 3 and DHA (1:2) were investigated in order to evaluate the potential synergism effect of the hybrid complexes. Outstandingly, 2a-c displayed significantly higher potency on PC-3 cells than auranofin (16 to 55 -fold), DHA (22 to 78 -fold), complex 3 (10 to 35-fold) and a 2:1 mixture of DHA and 3 (16 to 55 -fold). Moreover, they were 6.2 to 16.7 more selective towards cancer cells than NIH3T3 compared to the two drug references auranofin and DHA. Remarkably, 2a shows a PC-3/RPWE-1 SI value close to that of DHA but 69 times higher than that obtained for both gold references, auranofin and 3 .
Table 1. Cytotoxicity and selectivity of $\mathbf{1 a - c}$ and $\mathbf{2 a - c}$ on PC-3 prostate cancer cells versus non tumoral NIH3T3 mouse embryonic fibroblasts and RWPE-1

\begin{tabular}{|c|c|c|c|c|c|}
\hline & PC-3 & NIH3T3 & $S I^{[b]}$ & RWPE-1 & $\left.S\right|^{[b]}$ \\
\hline $1 a$ & $>20$ & $>20$ & - & $>20$ & - \\
\hline $1 b$ & $>20$ & $>20$ & - & $>20$ & - \\
\hline 1c & $>20$ & $>20$ & - & 3.74 & - \\
\hline $2 a$ & 0.070 & 1.13 & 16.2 & 0.480 & 6.9 \\
\hline $2 b$ & 0.042 & 0.700 & 16.7 & 0.110 & 2.6 \\
\hline 2c & 0.020 & 0.310 & 15.5 & 0.098 & 4.9 \\
\hline Auranofin & 1.09 & 1.10 & 1.0 & 0.084 & 0.1 \\
\hline DHA & 1.56 & 3.86 & 2.5 & 9.68 & 6.5 \\
\hline 3 & 0.695 & 7.98 & 11.8 & 0.112 & 0.1 \\
\hline 3 / DHA (1:2) & 1.09 & 2.85 & 2.6 & 0.218 & 0.2 \\
\hline
\end{tabular}
human prostatic epithelial cells $\left(\mathrm{Gl}_{50}[\mu \mathrm{M}], 72 \mathrm{~h}, \mathrm{MTT}\right.$ assay). ${ }^{[a]}$

[a] The $\mathrm{GI}_{50}$ values represent the concentration of compound causing $50 \%$ inhibition of cell growth. Mean of at least three independent experiments. [b] Selectivity index $\left(\left(\mathrm{SI}=\mathrm{GI}_{50}\right.\right.$ (non-cancer cell line) $/ \mathrm{GI}_{50}$ (cancer cell line)).

Overall, these results highlight that linking a derivative of DHA on the NHC scaffold of a bisNHC gold(I) unit results in high cytotoxicity combined with high selectivity. Due to its better selectivity, 2a was chosen for further biological investigations. Besides PC-3 prostate cancer, $2 \mathbf{a}$ was thus tested on a panel of seven other representative human cancer cell models, namely 
A549 (lung), U-2 OS (bone), MCF-7 (breast), T24 (bladder), LAMA (chronic myeloid leukemia), HL-60 (acute myeloid leukemia) and HepG2 (liver). An additional noncancerous cell line, the MC3T3 pre-osteoblastic cell line was also tested (Table 2).

Table 2. Cytotoxicity of $\mathbf{2 a}$, auranofin, DHA, $\mathbf{3}$ and a mixture of $\mathbf{3}$ and DHA (1:2 ratio) on a representative panel of cancer cell lineages and the non tumoral MC3T3 mouse osteoblastic cell line $\left(\mathrm{GI}_{50}[\mu \mathrm{M}], 72 \mathrm{~h}, \mathrm{MTT}\right.$ assay) ${ }^{[\mathrm{a}]}$

\begin{tabular}{|c|c|c|c|c|c|c|c|c|}
\hline & $\begin{array}{l}\text { A549 } \\
\text { Lung }\end{array}$ & $\begin{array}{c}\text { U-2 OS } \\
\text { Bone }\end{array}$ & $\begin{array}{l}\text { MCF-7 } \\
\text { Breast }\end{array}$ & $\begin{array}{c}\text { T24 } \\
\text { Bladder }\end{array}$ & $\begin{array}{l}\text { LAMA } \\
\text { CML }\end{array}$ & $\begin{array}{c}\mathrm{HL}-60 \\
\mathrm{AML}\end{array}$ & $\begin{array}{c}\text { HepG2 } \\
\text { Liver }\end{array}$ & $\begin{array}{c}\text { MC3T3 } \\
\text { Bone }\end{array}$ \\
\hline $2 a$ & 0.115 & 0.122 & 0.089 & 0.175 & 0.079 & 0.017 & 2.16 & 1.62 \\
\hline Auranofin & 4.41 & 0.474 & 1.39 & 1.10 & 0.809 & 0.951 & 3.62 & 1.39 \\
\hline DHA & 11.1 & 4.10 & 9.67 & 4.99 & 5.60 & 3.25 & 12.0 & 3.55 \\
\hline 3 & 1.16 & 2.51 & 0.380 & 0.191 & 0.662 & 0.500 & 5.23 & 17.9 \\
\hline 3 / DHA (1:2) & 1.99 & 1.25 & 0.610 & 0.319 & 0.800 & 0.471 & 4.71 & 1.76 \\
\hline
\end{tabular}

[a] The $\mathrm{GI}_{50}$ values represent the concentration of compound causing $50 \%$ inhibition of cell growth. Mean of at least three independent experiments.

As in the case of PC-3 cells, the $\mathrm{Gl}_{50}$ values for six cancer cell lines were in the lower $\mathrm{nM}$ range spanning from 79 to $175 \mathrm{nM}$. Overall, 2a exhibited a much stronger potency than auranofin (15-fold), DHA (60-fold), complex 3 (9-fold) and the mixture of 3 and DHA (10-fold) in the representative prostate, lung, bone, breast, bladder and leukemia cells. Of note, 2a was 13.3 times more selective towards U-2 OS bone cancer cells than MC3T3 normal bone cells, much higher than auranofin (2.9-fold), whereas DHA did not express any selectivity. The efficacy of $2 a$ was confirmed using a clonogenic assay (or colony formation assay). ${ }^{[9]}$ At concentrations above $100 \mathrm{nM}$, no visible colony of PC-3 prostate or T24 bladder cells could be observed, indicating the ability of $\mathbf{2 a}$ to completely abolish the capacity of these cells to proliferate (Suppl. Fig 1).

Overall, these results show that hybrid complex $\mathbf{2 a}$ is extensively more effective than the control molecules used in this study on all the tested cancer cell line models, even on hepatocellular carcinoma HepG2, a cancer model notoriously known to be difficult to treat by chemotherapy, ${ }^{[10]}$ suggesting that gold(I)artemisinin like hybrid complexes could represent potential novel anticancer drugs.

\section{ROS, NRF2, chemosensitizing effects, NF-kB and HIF}

In order to better understand the difference between $\mathbf{2} \mathbf{a}$ and the reference molecules, some mechanistic aspects have been investigated. High reactive oxygen species (ROS) levels are harmful to cells, and oxidative stress can have a tumorsuppressive effect. ${ }^{21}$ ROS levels were increased after treatment with auranofin or $\mathbf{2 a}$, and a weaker effect on ROS formation was noted for DHA in some cell lines (Suppl. Fig 2). In general, no significant differences in the amount of generated ROS were observed across cell lines and treatments, suggesting that the amount of ROS produced could not explain the differential antitumor efficacies among treatments. The behavior of cell lines to ROS-mediated cell death is strongly dependent on antioxidant enzymes or oxidative stress regulators. In this respect, the NRF2 antioxidant response pathway plays a fundamental role to protect our body against drug toxicity and stress-induced diseases, by notably regulating the basal and inducible expression of detoxification and antioxidant enzymes. ${ }^{[12]}$
Although NRF2 activation is normally beneficial for health, it has undesirable effects in cancer, promoting malignant progression by conferring chemo-and radioresistance, as well as promoting metabolic reprogramming. ${ }^{[12,13]}$ To quantify NRF2 antioxidant response activity, we relied on an ARE Reporter - HepG2 liver cancer cell model containing a firefly luciferase gene under the control of a stably integrated ARE (antioxidant response element). Tert-butylhydroquinone ( $\mathrm{tBHQ}$ ) was used to validate the response to stimulation of the ARE Reporter - HepG2 cell line (Fig 2a). Both auranofin and DHA (and its bioactive derivatives) have been extensively reported to stimulate NRF2 transcriptional activity in various physio(patho)logical conditions including in cancer. ${ }^{[14]}$ Indeed, the treatment with auranofin (Fig $2 \mathrm{~b})$ or DHA (Fig 2c) markedly increased NRF2 transcriptional activity. To the best of our knowledge ARE activity monitoring has never been reported with cationic bisNHC gold(I) complexes such as 3 . In contrast to auranofin and DHA, 3 treatment was associated with a stimulation of ARE activity mostly significant beyond $1 \mu \mathrm{M}$ (Fig 2d). Unexpectedly, owing to the fact that both DHA and 3 stimulated ARE activity in HepG2 cell line, treatment with hybrid complex 2a was associated with a remarkable dosedependent inhibition of NRF2 transcriptional activity starting as low as $10 \mathrm{nM}$ dose (Fig 2e), and a calculated $\mathrm{IC}_{50}$ of $850 \mathrm{nM}$. To substantiate this finding, we also monitored NRF2 transcriptional activity, by using an inducible ARE Reporter containing a renilla luciferase gene in a second model, the MCF7 breast cancer cells. As shown in Fig 2f, 2a was again able to inhibit NRF2 transcriptional activity induced by $10 \mu \mathrm{M}$ of $\mathrm{tBHQ}\left(\mathrm{IC}_{50}=1.14\right.$ $\mu \mathrm{M})$ whereas neither auranofin, DHA nor complex 3 were capable of suppressing $\mathrm{tBHQ}$-induced NRF2 activity (data not shown).

NRF2 is recognized to directly regulate the ATP-binding cassette $(A B C)$ superfamily multidrug efflux pumps expression in a number of human tumors. ${ }^{[15]}$ Overexpression of such multidrug-resistance-associated proteins including MRP1 or MDR1 is recognized as a major impediment to successful chemotherapies in vitro and in vivo. ${ }^{[16]}$ To further substantiate a role for $\mathbf{2 a}$ as a potential anticancer drug, we evaluated its efficacy towards multidrug-resistant HL-60 acute myeloid leukemia cells. ${ }^{[17]}$ 

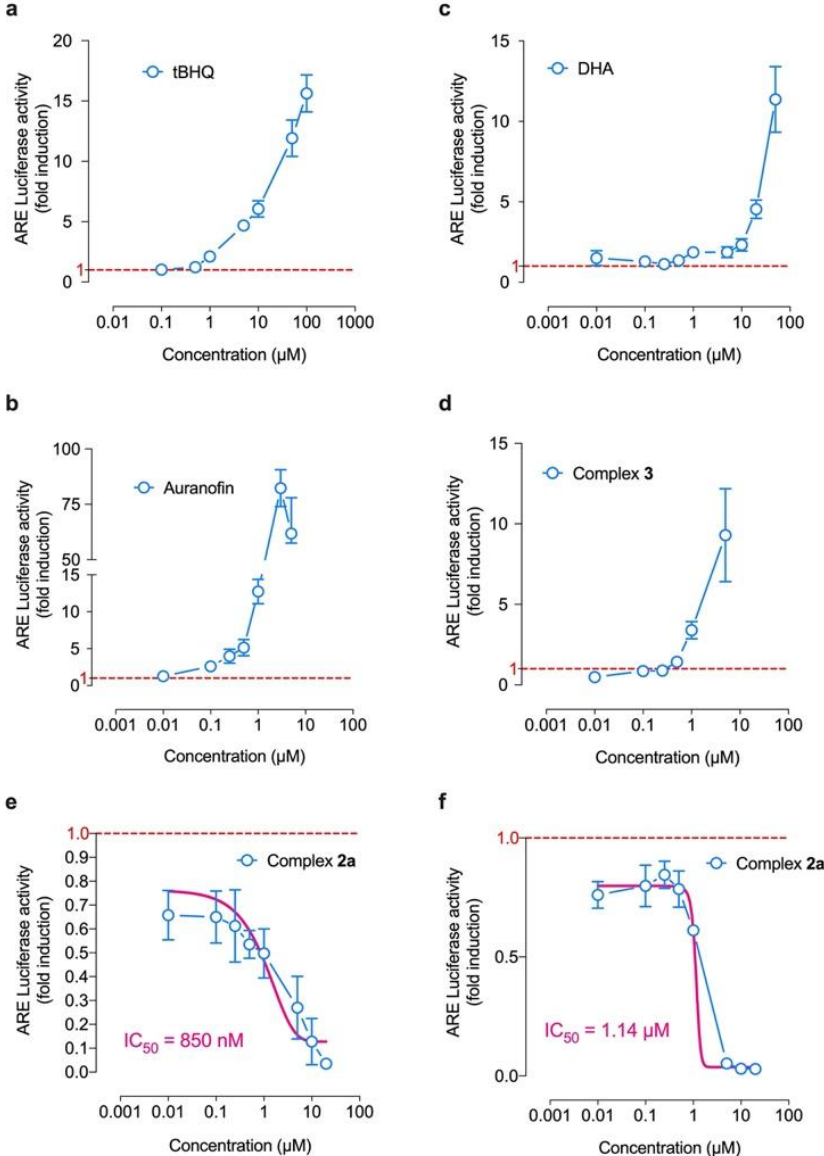

Concentration $(\mu \mathrm{M})$

Figure 2. Complex 2a inhibits NRF2 transcriptional activity. a-e, NRF2 transcriptional activity was evaluated in HepG2 cancer cell model treated with tBHQ, auranofin, DHA, 3 and $\mathbf{2 a}$ compounds. The ARE Reporter - HepG2 cell line contains a firefly luciferase gene under the control of ARE stably integrated into HepG2 cells. This cell line is validated for the response to the stimulation of tert-butylhydroquinone (tBHQ). $\mathbf{f}$, the inhibitory effect of $2 a$ was evaluated in NRF2 ARE - Responsive Renilla Reporter MCF-7 human breast cancer, stimulated by $10 \mu \mathrm{M} \mathrm{tBHQ}$ for $7 \mathrm{~h}$. Mean of at least three independent experiments \pm SD.

Contrary to parental HL-60 cells (Fig 3a), both doxorubicin and etoposide failed to trigger cell death in chemoresistant $\mathrm{HL}$ 60/Doxo (Fig 3b) and HL-60/VP16 cells (Fig 3c). Noteworthy, 2a could overcome resistance in both HL-60/Doxo (Fig 3b) and HL60/VP16 cells (Fig 3c), with $\mathrm{Gl}_{50}$ values similar to the one calculated for the chemosensitive parental HL-60 cells. In line with previous reports showing that NRF2 genetic silencing could restore chemosensitivity through a significant downregulation of NRF2-targeted ATP-binding cassette (ABC) efflux transporters, our data suggest that 2a could overcome multidrug-associated chemoresistance. We next attempted to study a potential chemosensitizing effects of $\mathbf{2 a}$ particularly in liver cancer, where the multiple kinase inhibitor sorafenib is the first-line systemic therapy since 2007. Yet, sorafenib has been shown to provide limited survival benefits, suggesting the existence of primary and acquired drug resistance mechanisms, and several lines of evidence suggest a key role for NRF2 signaling. First, somatic mutations of NRF2 and Keap1 - the repressor protein that binds to NRF2 and promotes its degradation by the ubiquitin proteasome pathway - have been documented in hepatocarcinoma. ${ }^{[18]}$
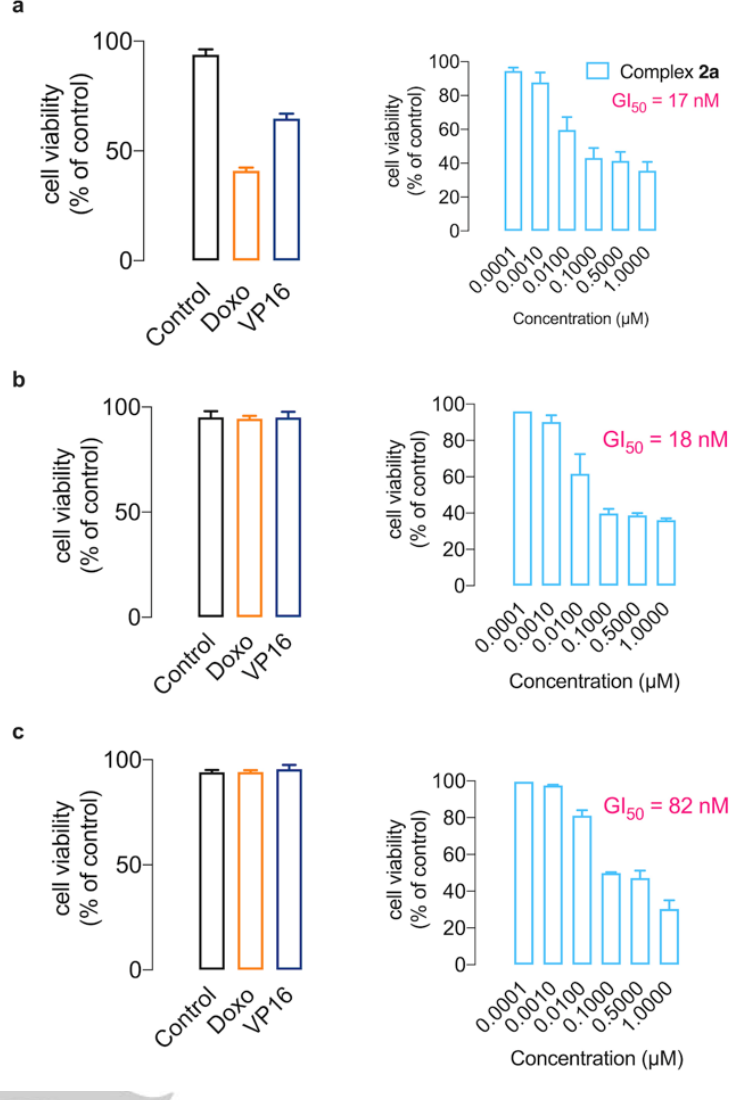

Figure 3. Complex 2a overcomes chemoresistance in HL-60 acute myeloid leukemia.Parental HL-60 cells (a), HL-60/Doxo (b) and HL-60/VP16 (c) were incubated in the absence or presence of $1 \mathrm{mM}$ doxorubicin or $5 \mathrm{mM}$ etoposide (VP16) or with increasing concentration of $2 \mathrm{a}$ for $72 \mathrm{~h}$. $\left(\mathrm{GI}_{50}[\mu \mathrm{M}], 72 \mathrm{~h}, \mathrm{MTT}\right.$ assay). ${ }^{[a]}$ Mean of at least three independent experiments $\pm S D$.

Second, exome analyses have shown that NRF2 is a driver gene for liver carcinogenesis. ${ }^{[19]}$ Third, sorafenib itself can augment both mRNA and protein levels of NRF2 in hepatocarcinoma. ${ }^{[20]}$ In that regard, Sun and co-workers recently demonstrated that shRNA strategy against NRF2 was able to significantly enhance the anticancer activity of sorafenib in hepatocarcinoma cell and animal models. ${ }^{[20 a]}$ Accordingly, we hypothesized that the NRF2 inhibitory effect of $2 a$ could sensitize to sorafenib in HepG2 cells. The treatment of HepG2 cells with sorafenib was indeed associated with a significant increase in NRF2 transcriptional activity (Fig 4a). As anticipated, 2a remarkably reversed the NRF2 transcriptional activity surge induced by sorafenib, starting as low as $10 \mathrm{nM}$ dose, with a calculated $\mathrm{IC}_{50}$ of $511 \mathrm{nM}$ (Fig 4b). To establish the proof-ofconcept that complex $\mathbf{2 a}$ could therefore serve as a sensitizing agent for sorafenib in hepatocarcinoma, we relied on an isobologram analysis. ${ }^{[21]}$ Complex $2 a$ displayed a $\mathrm{Gl}_{50}$ value of $2.4 \mu \mathrm{M}$ toward HepG2 (Table 2) whereas the $\mathrm{Gl}_{50}$ of sorafenib value was achieved at $4.1 \mu \mathrm{M}$. We exposed HepG2 cells to fixed doses of sorafenib ( 1 and $2.5 \mu \mathrm{M})$ in combination with several doses of $2 \mathbf{a}$ ranging from $1 \mathrm{nM}$ to $1 \mu \mathrm{M}$, or to fixed doses of $\mathbf{2 a}$ (500 nM and $1 \mu \mathrm{M}$ ) combined with $10 \mathrm{nM}$ to $5 \mu \mathrm{M}$ sorafenib (Fig $4 c)$. 
a

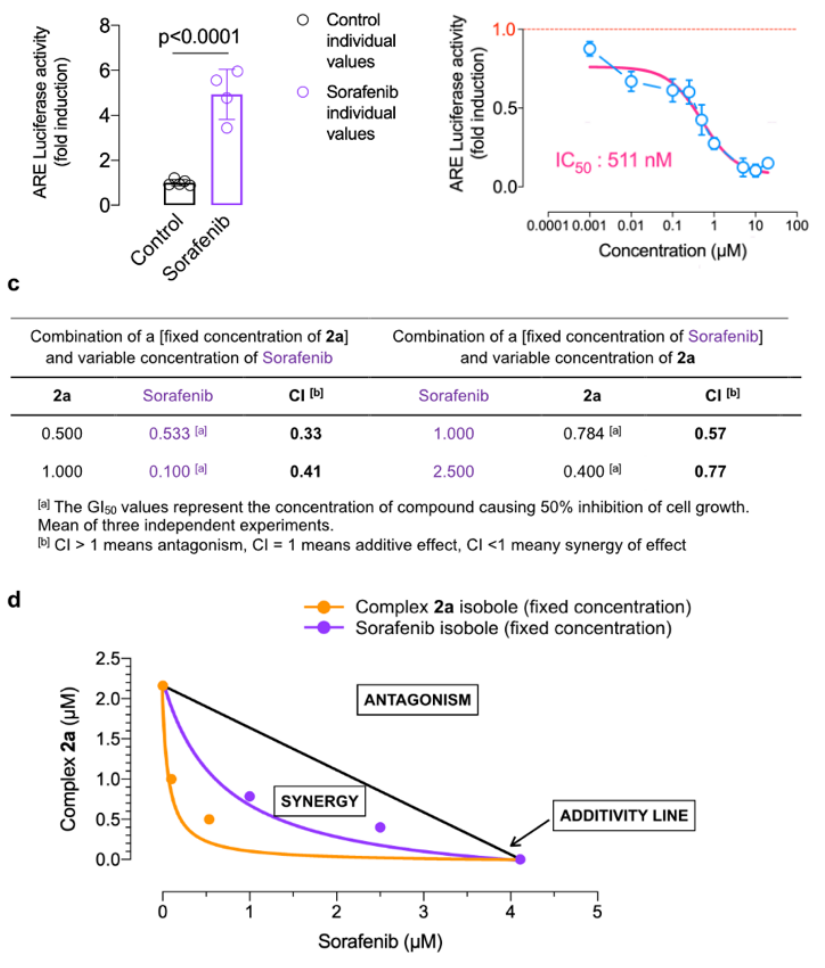

Figure 4. Complex 2a sensitizes to sorafenib in HepG2 cells through inhibition of NRF2 activity. a, NRF2 transcriptional activity was evaluated in HepG2 cancer cell model treated with $1 \mu \mathrm{M}$ of sorafenib for $7 \mathrm{~h}$. The ARE Reporter HepG2 cell line contains a firefly luciferase gene under the control of ARE stably integrated into HepG2 cells. $\mathbf{b}$, the inhibitory effect of $\mathbf{2 a}$ compound was evaluated ARE Reporter - HepG2 cell line treated with $1 \mu \mathrm{M}$ of sorafenib for $7 \mathrm{~h}$. c, Combination Index $(\mathrm{Cl})$ of $\mathbf{2 a}$ and sorefenib on HepG2 liver cancer cells $\left(\mathrm{Gl}_{50}[\mu \mathrm{M}], 72 \mathrm{~h}, \mathrm{MTT}\right.$ assay). $\mathbf{d}$, Isobologram for $\mathrm{Gl}_{50}$ values in which the dose of $2 \mathrm{a}$ alone is $2.16 \mu \mathrm{M}$ and Sorafenib alone is $4.11 \mu \mathrm{M}$. The straight line connecting these intercept points (additivity line) is the locus of all dose pairs that, based on these potencies, should give the same effect. All tested dose pairs attain this effect with lesser quantities and are superadditive or synergistic.

In all tested combinations, the synergy of effect was remarkable with calculated combination indexes $(\mathrm{Cl})$ significantly below the value of 1 that represents an additive effect (Fig 4c). Of note, as shown by the $\mathrm{Cl}$ values (Fig 4c) and the isoboles (Fig 4d), a better synergism was observed with fixed concentration $2 \mathbf{2 a}$ clearly indicating that inhibition of NRF2 activity by $\mathbf{2 a}$ counteracts a mechanism of resistance hereby sensitizing hepatocarcinoma cells to sorafenib.

Besides NRF2, two other major transcription factors have been reported to be modulated by artemisinin (and derivatives) or gold-containing drugs, namely NF-kB and Hypoxia Inducible Factor (HIF). Beyond inflammation, the NF-KB pathway is also involved extensively in cancer development and progression. ${ }^{[22]}$ We made use of a A549 lung cancer cell model in which NF-KB luciferase reporter construct is stably integrated to quantify NF$\mathrm{KB}$ activity. Stimulation of NF-KB was conducted with the TNFa cytokine, and peaked after 7 hours of treatment (Suppl. Fig 3a). Auranofin has been previously reported to inhibit NF-kB activation regardless of the nature of the stimulus (TNFa, IL-1 $1 \beta$, LPS) in various cell systems, including cancer. ${ }^{[23]} A$ wealth of reports also establish that artemisinin derivatives inhibit NF-KB activation in numerous solid cancer and hematological cell lineages. ${ }^{[24]}$ Both auranofin and DHA inhibited NF-KB activity triggered by TNFa (Suppl. Fig $3 \mathrm{~b}$ ) with $\mathrm{IC}_{50}$ values reminiscent of their capability to inhibit cell proliferation. 2a remarkably suppressed NF-KB activity at very low concentrations $\left(\mathrm{IC}_{50}=627\right.$ $\mathrm{nM}$, Suppl. Fig 3b), surpassing the well-established effect of auranofin, which has been originally described as an antiinflammatory drug $\left(\mathrm{IC}_{50}\right.$ of $627 \mathrm{nM}$ versus $2.97 \mu \mathrm{M}$ in our cell model). The inhibitory effect of $\mathbf{2 a}$ might be related to the cationic bisNHC gold(I) moiety, also present in complex $\mathbf{3}$, which exhibited similar efficacy towards NF-kB activity $\left(\mathrm{IC}_{50}=664 \mathrm{nM}\right.$, Suppl. Fig 3b).

Hypoxia is a hallmark of solid tumors, and the adjustment of tumor cells to the lack of oxygen is critical for the development of aggressive tumor phenotype ${ }^{[25]}$ and associated with treatment resistance, metabolic reprogramming, immune evasion and poor clinical prognosis. ${ }^{[26]}$ Recent studies have shown that auranofin could sensitize hypoxic tumor cells to irradiation ${ }^{[27]}$, and could inhibit the accumulation of $\mathrm{HIF}-1 \alpha$, the master transcription factor that regulates response to hypoxia. ${ }^{[28]}$ The HRE-Luc Reporter Cell Line-HeLa stably expressing luciferase reporter gene under the control of the hypoxia response element (HRE) was employed to study the hypoxia signaling pathway. In line with the aforementioned studies, HRE-mediated transcription was remarkably decreased by auranofin treatment in HeLa cells (Suppl. Fig 3c) with an $\mathrm{IC}_{50}$ of $745 \mathrm{nM}$. DHA also inhibited HIF activity to a lesser extent similar to its effect on NF-KB activity $\left(\mathrm{IC}_{50}>10 \mu \mathrm{M}\right)$. This is in line with a number of studies establishing the anti-hypoxic and subsequent anti-angiogenesis effects of artemisinin and derivatives in cancer cells. ${ }^{[29]}$ The effect of cationic bisNHC gold(I) on HIF activity has never been reported prior this study. As shown in Suppl. Fig 3c, complex 3 also inhibited HIF activity $\left(\mathrm{IC}_{50}=2.0 \mu \mathrm{M}\right)$. In keeping with its remarkable effect on NRF2 and NF-KB transcriptional activities, complex 2a strongly impeded HRE-mediated transcription under hypoxia in HeLa cells with and $\mathrm{IC}_{50}$ of $942 \mathrm{nM}$ (Suppl. Fig 3c).

\section{Conclusion}

Hybrid-complex 2a displayed a remarkable selectivity and efficacy in killing a broad range of tumor cell models including solid tumors (prostate, bladder, bone, lung, breast, liver) and hematological tumors (CML, AML). The average $\mathrm{Gl}_{50}$ was below $100 \mathrm{nM}$ (17 to $175 \mathrm{nM}$ range) for all cancer cell models except for the hepatocarcinoma HepG2 cells $\left(\mathrm{GI}_{50}=2.16 \mu \mathrm{M}\right)$, a model notoriously known to be refractory to chemotherapy. Importantly, for all tested cancer cell models, 2a outperformed the drugs of reference used in this study, auranofin and DHA, both of which have been proposed for drug repurposing in cancer and are currently used in several phase $\mathrm{I} / \mathrm{II}$ and phase II/III clinical trials (source: National Cancer Institute). Of note, 2a also presented a better specificity than auranofin and DHA for cancer cells vis-àvis non cancer models (epithelial cells, osteoblasts and fibroblasts). Moreover, 2a could overcome the multidrug resistance phenotype observed in malignant AML HL-60 cells exposed to anthracyclines (doxorubicin) or plant-based alkaloids (etoposide), which remains a major obstacle to successful chemotherapy. Although 2a shares some common features with auranofin or DHA regarding its impact on TrxR inhibition or ROS production, its mechanism of action appears quite distinctive. Similarly to auranofin or DHA, 2a could inhibit NF-KB and HIF 
(Hypoxia Inducible Factor) activities, yet in a steadily efficacy. Noteworthy, contrary to auranofin or DHA, 2a remarkably impeded NRF2 activity with an inhibitory effect seen at all tested concentrations (as low as nM). The elevated activity of NRF2 in cancer cells decreases sensitivity to ionizing radiations or chemotherapies, inhibiting NRF2 signaling is thus highly desirable to improve the efficacy of the treatments. In this regard hepatocarcinoma is an ideal example and our data reveal that 2a dramatically sensitizes to sorafenib in the HepG2 cells, where aberrant NRF2 activity is further amplified by sorafenib. There was a stunning synergy of effect when $2 a$ was combined to sorafenib, certainly indicating that inhibition of NRF2 activity by 2a counteracts this mechanism of resistance hereby sensitizing hepatocarcinoma cells to sorafenib. Our data potentially shed light on $\mathbf{2 a}$ as a potential sorafenib sensitizing agent to allow more effective therapeutic regimens designed for hepatocarcinoma patients. The search for inhibitors of a transcription factor such as NRF2 remains a major challenge in pharmacology as transcription factors are typically considered "undruggable". [30]

The mechanism(s) by which $\mathbf{2 a}$ inhibits three majors NF-KB, HIF and NRF2 transcriptional activities involved in cancer progression and resistance warrants further investigation. A better appreciation of its mechanism(s) of action, notably its unique effect towards NRF2, is needed before we can fully determine its therapeutic value in preclinical models.

\section{Acknowledgements}

This work was supported by the Centre National de la Recherche Scientifique (CNRS) and CZ thanks the Chinese Scholarship Council (CSC) for PhD fellowship.

Keywords: metallodrugs $\cdot$ chemoresistance $\cdot$ cancer $\cdot$ NF-KB • $\mathrm{HIF} \cdot$ sorefanib $\bullet$ NRF2

[1] WHO, WHO ed., World Health Organization, Geneva, 2019, p. 232.

[2] a) S. Krishna, L. Bustamante, R. K. Haynes, H. M. Staines, Trends Pharmacol Sci 2008, 29, 520-527; b) T. Efferth, Semin Cancer Biol 2017, 46, 65-83; c) T. Efferth, Biotechnol Adv 2018, 36, 1730-1737; d) Y. K. Wong, C. Xu, K. A. Kalesh, Y. He, Q. Lin, W. S. F. Wong, H. M. Shen, J. Wang, Med Res Rev 2017, 37, 1492-1517.

[3] a) C. J. Zhang, J. Wang, J. Zhang, Y. M. Lee, G. Feng, T. K. Lim, H. M. Shen, Q. Lin, B. Liu, Angew Chem Int Ed Engl 2016, 55, 13770-13774 b) N. Eling, L. Reuter, J. Hazin, A. Hamacher-Brady, N. R. Brady, Oncoscience 2015, 2, 517-532; c) E. Ooko, M. E. Saeed, O. Kadioglu, S. Sarvi, M. Colak, K. Elmasaoudi, R. Janah, H. J. Greten, T. Efferth, Phytomedicine 2015, 22, 1045-1054.

[4] a) T. Zou, C. N. Lok, P. K. Wan, Z. F. Zhang, S. K. Fung, C. M. Che, Curr Opin Chem Biol 2018, 43, 30-36; b) S. Jurgens, A. Casini, Chimia (Aarau) 2017, 71, 92-101; c) M. Porchia, M. Pellei, M. Marinelli, F. Tisato, F. Del Bello, C. Santini, Eur J Med Chem 2018, 146, 709-746; d) W. Liu, R. Gust, Coord. Chem. Rev. 2016, 329, 191-213.

[5] a) L. Boselli, I. Ader, M. Carraz, C. Hemmert, O. Cuvillier, H. Gornitzka, Eur J Med Chem 2014, 85, 87-94; b) C. Zhang, C. Hemmert, H. Gornitzka, O. Cuvillier, M. Zhang, R. W. Sun, ChemMedChem 2018, 13, 1218-1229; c) C. Zhang, M. L. Maddelein, R. Wai-Yin Sun, H. Gornitzka, O. Cuvillier, C. Hemmert, Eur J Med Chem 2018, 157, 320-332.

[6] R. K. Haynes, H. W. Chan, M. K. Cheung, W. L. Lam, M. K. Soo, H. W. Tsang, A. I. Voerste, D. Williams, Eur. J. Org. Chem. 2002, 113-132.

[7] C. Roder, M. J. Thomson, Drugs R D 2015, 15, 13-20.

[8] L. Paloque, C. Hemmert, A. Valentin, H. Gornitzka, Eur J Med Chem 2015, 94, 22-29.
[9] N. A. Franken, H. M. Rodermond, J. Stap, J. Haveman, C. van Bree, Nat Protoc 2006, 1, 2315-2319.

[10] M. Ikeda, C. Morizane, M. Ueno, T. Okusaka, H. Ishii, J. Furuse, Jpn J Clin Oncol 2018, 48, 103-114.

[11] C. Gorrini, I. S. Harris, T. W. Mak, Nat Rev Drug Discov 2013, 12, 931 947.

[12] M. Yamamoto, T. W. Kensler, H. Motohashi, Physiol Rev 2018, 98, 1169-1203.

[13] a) T. Suzuki, H. Motohashi, M. Yamamoto, Trends Pharmacol Sci 2013 34, 340-346; b) Y. Mitsuishi, K. Taguchi, Y. Kawatani, T. Shibata, T. Nukiwa, H. Aburatani, M. Yamamoto, H. Motohashi, Cancer Cell 2012, 22, 66-79.

[14] a) G. Tanaka, K. Inoue, T. Shimizu, K. Akimoto, K. Kubota, Cancer Med 2016, 5, 2544-2557; b) P. V. Raninga, G. Di Trapani, S. Vuckovic, K. F. Tonissen, Redox Biol 2016, 8, 175-185; c) W. Chen, S. Li, J. Li, W Zhou, S. Wu, S. Xu, K. Cui, D. D. Zhang, B. Liu, FASEB J 2016, 30, 2500-2510; d) J. L. Roh, E. H. Kim, H. Jang, D. Shin, Redox Biol 2017, 11, 254-262; e) D. Oommen, D. Yiannakis, A. N. Jha, Mutat Res 2016, 784-785, 8-15.

[15] X. Bai, Y. Chen, X. Hou, M. Huang, J. Jin, Drug Metab Rev 2016, 48, 541-567.

[16] a) G. Szakacs, J. K. Paterson, J. A. Ludwig, C. Booth-Genthe, M. M. Gottesman, Nat Rev Drug Discov 2006, 5, 219-234; b) P. Sonneveld, J Intern Med 2000, 247, 521-534.

[17] a) P. Sonneveld, J Intern Med 2000, 247, 521-534; b) C. H. Wu, M Rastegar, J. Gordon, A. R. Safa, Oncogene 2001, 20, 7006-7020.

[18] a) Y. Totoki, K. Tatsuno, K. R. Covington, H. Ueda, C. J. Creighton, M. Kato, S. Tsuji, L. A. Donehower, B. L. Slagle, H. Nakamura, S. Yamamoto, E. Shinbrot, N. Hama, M. Lehmkuhl, F. Hosoda, Y. Arai, K. Walker, M. Dahdouli, K. Gotoh, G. Nagae, M. C. Gingras, D. M. Muzny, H. Ojima, K. Shimada, Y. Midorikawa, J. A. Goss, R. Cotton, A Hayashi, J. Shibahara, S. Ishikawa, J. Guiteau, M. Tanaka, T. Urushidate, S. Ohashi, N. Okada, H. Doddapaneni, M. Wang, Y. Zhu, H. Dinh, T. Okusaka, N. Kokudo, T. Kosuge, T. Takayama, M. Fukayama, R. A. Gibbs, D. A. Wheeler, H. Aburatani, T. Shibata, Nat Genet 2014 46, 1267-1273; b) J. C. Nault, S. Rebouissou, J. Zucman Rossi, Hepatology 2015, 62, 677-679.

[19] K. Schulze, S. Imbeaud, E. Letouze, L. B. Alexandrov, J. Calderaro, S Rebouissou, G. Couchy, C. Meiller, J. Shinde, F. Soysouvanh, A. L. Calatayud, R. Pinyol, L. Pelletier, C. Balabaud, A. Laurent, J. F. Blanc, V. Mazzaferro, F. Calvo, A. Villanueva, J. C. Nault, P. Bioulac-Sage, M. R. Stratton, J. M. Llovet, J. Zucman-Rossi, Nat Genet 2015, 47, 505511.

[20] a) X. Sun, Z. Ou, R. Chen, X. Niu, D. Chen, R. Kang, D. Tang Hepatology 2016, 63, 173-184; b) T. Bai, P. Lei, H. Zhou, R. Liang, R Zhu, W. Wang, L. Zhou, Y. Sun, J Cell Mol Med 2019, 23, 7349-7359.

[21] L. Zhao, J. L. Au, M. G. Wientjes, Front Biosci (Elite Ed) 2010, 2, 241249.

[22] a) Y. Xia, S. Shen, I. M. Verma, Cancer Immunol Res 2014, 2, 823-830 b) Y. Ben-Neriah, M. Karin, Nat Immunol 2011, 12, 715-723; c) C. Y Wang, J. C. Cusack, Jr., R. Liu, A. S. Baldwin, Jr., Nat Med 1999, 5, 412-417.

[23] a) A. Nakaya, M. Sagawa, A. Muto, H. Uchida, Y. Ikeda, M. Kizaki, Leuk Res 2011, 35, 243-249; b) M. Kiebala, J. Skalska, C. Casulo, P. S Brookes, D. R. Peterson, S. P. Hilchey, Y. Dai, S. Grant, S. B. Maggirwar, S. H. Bernstein, Exp Hematol 2015, 43, 89-99.

[24] a) O. Thanaketpaisarn, P. Waiwut, H. Sakurai, I. Saiki, Int J Oncol 2011, 39, 279-285; b) S. J. Wang, Y. Gao, H. Chen, R. Kong, H. C. Jiang, S H. Pan, D. B. Xue, X. W. Bai, B. Sun, Cancer Lett 2010, 293, 99-108; c) J. Jiang, G. Geng, X. Yu, H. Liu, J. Gao, H. An, C. Cai, N. Li, D. Shen, X. Wu, L. Zheng, Y. Mi, S. Yang, Oncotarget 2016, 7, 87271-87283; d) J. J. Nunes, S. K. Pandey, A. Yadav, S. Goel, B. Ateeq, Neoplasia 2017, 19, 333-345.

[25] G. L. Semenza, Cell 2012, 148, 399-408

[26] P. Vaupel, A. Mayer, Cancer Metastasis Rev 2007, 26, 225-239.

[27] H. Wang, S. Bouzakoura, S. de Mey, H. Jiang, K. Law, I. Dufait, C Corbet, V. Verovski, T. Gevaert, O. Feron, D. Van den Berge, G. Storme, M. De Ridder, Oncotarget 2017, 8, 35728-35742. 
[28] M. V. Rios Perez, D. Roife, B. Dai, M. Pratt, R. Dobrowolski, Y. Kang, X. Li, J. J. Augustine, R. Zielinski, W. Priebe, J. B. Fleming, Surgery Open Science 2019, 1, 56-63.

[29] a) Y. P. Vandewynckel, D. Laukens, A. Geerts, C. Vanhove, B. Descamps, I. Colle, L. Devisscher, E. Bogaerts, A. Paridaens, X. Verhelst, C. Van Steenkiste, L. Libbrecht, B. N. Lambrecht, S. Janssens, H. Van Vlierberghe, Eur J Gastroenterol Hepatol 2014, 26, 861-870; b) X. J. Huang, Z. Q. Ma, W. P. Zhang, Y. B. Lu, E. Q. Wei, J Pharm Pharmacol 2007, 59, 849-856; c) X. H. Wu, H. J. Zhou, J. Lee, Anticancer Drugs 2006, 17, 839-848.

[30] J. H. Bushweller, Nat Rev Cancer 2019, 19, 611-624. 


\section{Entry for the Table of Contents}

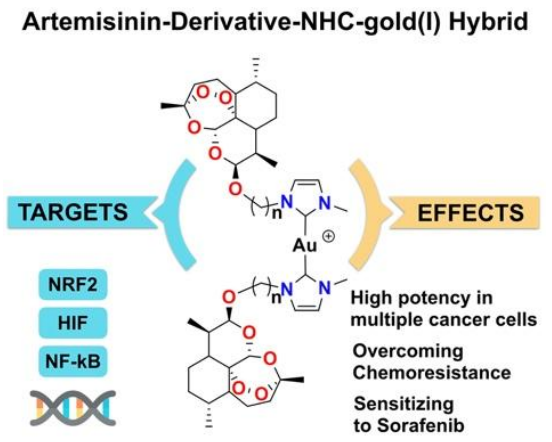

A gold(I) NHC-artemisinin hybrid complex has been synthesized and studied for anticancer properties. It shows remarkable selectivity and efficacy in killing a broad range of tumor cell models with average GI50 around $100 \mathrm{nM}$. It could overcome multidrug resistance, inhibits three major - NRF2, NF-KB and HIF - transcriptional activities involved in cancer progression and resistance, and strongly sensitize to sorafenib in liver cancer cells.

Institute and/or researcher Twitter usernames: @CUVILLIEROlivi1 ; @Chemeo2 